Article history

Received Oct 30, 2020

Accepted Apr 28, 2021

\title{
IMPLEMENTASI ITERATIVE DICHOTOMISER 3 (ID3) UNTUK PENENTUAN KELAYAKAN PEMBERIAN KREDIT PADA PT.BPR PLOSO SARANAARTHA JOMBANG
}

\author{
Siti Nurul Afiyah ${ }^{1}$, Wahyu Dini Aula Nabila ${ }^{1}$ \\ ${ }^{1}$ Program Studi Teknik Informatika, Fakultas Teknologi dan Desain, ITB Asia Malang \\ email: noeroel@asia.ac.id, wahyudini@asia.ac.id
}

\begin{abstract}
An PT. BPR Ploso Saranaartha Jombang has several problems that often arise regarding to the provision of credit to debtors. At present the bank is still giving credit to its customers by selecting debtors, there is no systematic procedure in determining whether a customer is eligible for credit or not. This is what causes a lot of bad credit that can harm the bank. Iterative Dichotomiser 3 (ID3) algorithm can be used to solve this case. In completing it, ID3 will do a data preprocessing process first, which aims to discard data that is not important to get the data that is needed. After that ID3 will form a decision tree based on the rules generated. Each root node in a decision tree is formed based on the rules generated. Each root node in a decision tree is formed based on the largest gain value of each input attribute. In calculating this algorithm, a sufficient dataset is needed to use the training process. The dataset used for this training process is 300 data records consisting of 272 data with good collectability and 28 data with bad collectability. There is also data that will be used for the testing process totaling 20 new customer data records consisting of 8 data with bad collectability and 12 data with good collectability. In the trials that have been carried out on the dataset produced 10 rules. After the data testing, the output with $88,51 \%$ accuracy is produced. This means that from 300 data records that have been trained, they can cover 19 data from 20 testing data records.
\end{abstract}

Keywords: classification, data mining, ID3, PT.BPR Ploso Saranaartha Jombang.

\begin{abstract}
Abstrak
Pada PT. BPR Ploso Saranaartha Jombang terdapat beberapa permasalahan yang kerap muncul mengenai pemberian kredit pada debitur. Saat ini bank tersebut memberikan kredit kepada nasabahnya masih dengan cara seleksi debitur, belum ada prosedur secara sistematis dalam menentukan apakah suatu nasabah tersebut layak diberikan kredit atau tidak. Hal inilah yang mengakibatkan banyaknya kredit macet yang dapat merugikan pihak bank.. Algoritma Iterative Dichotomiser 3 (ID3) merupakan salah satu algoritma yang dapat digunakan untuk menyelesaikan kasus ini. Dalam penyelesaiiannya nanti ID3 akan melakukan proses preprocessing data terlebih dahulu yang bertujuan untuk membuang data-data yang tidak penting guna mendapatkan data yang benar-benar dibutuhkan. Setelah itu ID3 akan membentuk sebuah pohon keputusan berdasarkan rules yang dihasilkan. Setiap root node dalam sebuah pohon keputusan terbentuk berdasarkan nilai gain terbesar dari tiap-tiap input atribut. Dalam perhitungan algoritma ini diperlukan sebuah dataset yang cukup untuk digunakan proses training. Dataset yang digunakan untuk proses training ini berjumlah 300 record data yang terdiri dari 272 data dengan kolektibilitas lancar dan 28 data dengan kolektibilitas macet. Terdapat pula data yang akan digunakan untuk proses testing berjumlah 20 record data nasabah baru yang terdiri dari 8 data dengan kolektibilitas macet dan 12 data dengan kolektibilitas lancar. Dalam uji coba yang telah dilakukan terhadap dataset menghasilkan 10 rules. Setelah dilakukan proses testing atau pengujian terhadap data testing dihasilkan output dengan tingkat keakurasian $88,51 \%$. Artinya dari 300 record data yang telah ditraining dapat meng-cover 19 data dari 20 record data testing.
\end{abstract}

Kata Kunci: klasifikasi, data mining, ID3, PT.BPR Ploso Saranaartha Jombang. 


\section{PENDAhUluan}

Pendahuluan Perkembangan teknologi yang semakin pesat menuntut suatu sistem untuk bekerja secara optimal agar dapat memenuhi kebutuhan suatu perusahaan atau instansi. Hal yang paling penting untuk dapat bersaing di era globalisasi ini adalah keakuratan suatu sistem beserta kecepatan aksesnya. Suatu sistem dapat dikatakan baik apabila sistem tersebut dapat mengolah data secara akurat dan cepat [1]. PT. BPR Ploso Saranaartha Jombang merupakan suatu bank perkreditan rakyat yang bergerak dalam bidang simpan pinjam. Dimana simpanan dalam bentuk deposito berjangka dan pinjaman dalam bentuk kredit modal kerja dan kredit umum.

Seiring dengan berkembangnya zaman, kebutuhan masyarakat yang selalu meningkat dan tidak ditunjang oleh suatu penghasilan. Maka pinjaman atau kredit menjadi salah satu jalan untuk memenuhi kebutuhan dan juga untuk keberlangsungan usaha masyarakat di era ini[2]. Sasaran kredit ini tidak hanya ditujukan kepada masyarakat lapisan menengah ke bawah tetapi juga seluruh lapisan masyarakat. Salah satu kredit yang paling banyak peminatnya pada PT. BPR Ploso Saranaartha Jombang adalah kredit umum. Kredit umum adalah kredit yang ditujukan kepada calon peminjam atau calon debitur secara umum untuk keperluan modal kerja atau kebutuhan lainnya dengan jangka waktu yang cukup lama yaitu lebih dari satu tahun.

Banyaknya pengajuan kredit pada PT. BPR Ploso Saranaartha Jombang membuat perusahaan kesulitan menentukan calon debitur yang tepat untuk diberi pinjaman dan juga proses penentuan kelayakan kredit pada perusahaan masih dengan cara seleksi debitur belum ada prosedur secara sistematis mengakibatkan banyak kredit yang macet. Dengan adanya permasalahan tersebut maka peran teknologi sangatlah penting untuk mendukung kegiatan sehari-hari termasuk perbankan. Salah satunya dengan menerapkan algoritma Iterative Dichotomiser Three (ID3). Algoritma ID3 merupakan contoh dari pemanfaatan struktur pohon dalam graf yang memanfaatkan hirarki dan memodelkan persoalan. ID3 dirancang untuk menghasilkan sebuah pohon keputusan yang memiliki kemampuan untuk mendapatkan keputusan secara cepat berdasarkan aturan yang telah ditentukan. Ada banyak peneliti yang sudah menerapkan algoritma ID3 dengan objek yang berbeda seperti halnya penelitian oleh Hariati dkk [3], dan juga penelitian yang dilakukan oleh Choina dkk dengan menerapkan algoritma ID3 untuk menyeleksi pegawai kontrak[4]. Penelitian yang terbaru mengenai penerapan ID3 dilakukan oleh Ilayani dkk dengan menerapkannya pada penilaian kredit pada PT. Mandala Multi Finance [5].

\section{METODE PENELITIAN}

Metode yang digunakan dalam penelitian ini diantaranya pengumpulan data pengajuan kredit pada PT.BPR Saranaartha Jombang, untuk selanjutya dianalisa menggunakan algoritma Iterative Dichotomiser 3 (ID3). Adapun flowchart dari algoritma Iterative Dichotomiser 3 (ID3) untuk menentukan pemberian kredit dari setiap nasabah disajikan dalam gambar 1 .

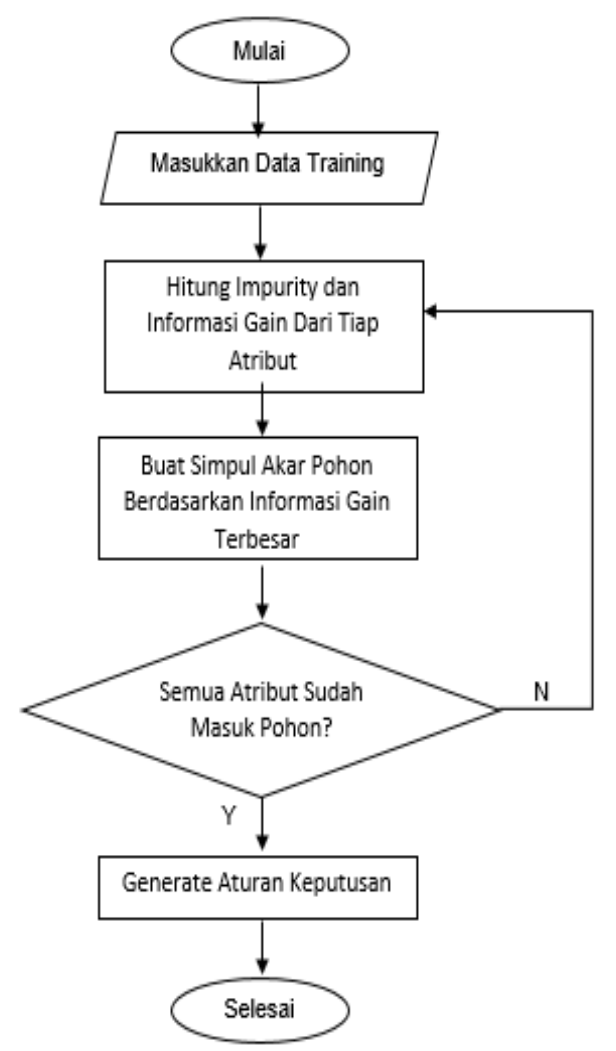

Gambar 1. Flowchart Algoritma Iterative Dichotomiser 3 (ID3)

Penjelasan Penjelasan dari flowchart pada Gambar 1 adalah sebagai berikut:

1. Pegawai menyiapkan data nasabah yang telah di preprocessing,

2. Menghitung informasi gain dan impurity dari masing-masing atribut. Jika data yang dihitung adalah data simbolik, maka nilai gain dan impurity dapat langsung dihitung dengan mencocokkan outputnya, namun jika datanya berupa 
data numerik, maka nilai yang dihitung harus disusun dari yang terkecil hingga yang terbesar, kemudian mencari transisi tiap masing-masing nilai antara output yang berbeda. Kemudian nilai gain dan impurity dapat dihitung,

3. Membuat simpul akar dari pemilihan atribut. Setelah nilai gain tiap atribut telah ditemukan, langkah selanjutnya adalah membandingkan nilai antara gain tersebut. Gain terbesar akan dijadikan simpul akar,

4. Jika data masih ada, kembali ke proses dua hingga ditemukan nilai gain lainnya. Jika perhitungan telah selesai, maka pohon keputusan dapat dibangun berdasarkan nilai gain yang terkumpul.

\section{HASIL DAN PEMBAHASAN}

\section{Bagian Perancangan Konsep Data Mining}

Perancangan konsep data mining merupakan bagaimana sebuah konsep yang dibuat dapat mempermudah dalam pengolahan proses input hingga output. Perancangan konsep data mining berisi beberapa tahapan, yaitu: tahapan seleksi database, proses cleaning, preprocessing, dan Analisa menggunakan algoritma ID3 [6].

\section{Dataset Awal}

Proses yang pertama kali dibutuhkan adalah menentukan informasi apa saja yang dibutuhkan dari database. Untuk lebih jelasnya informasi apa saja yang telah didapatkan dapat dilihat pada Tabel 1.

Tabel 1. Contoh Data Nasabah

\begin{tabular}{|r|r|l|r|r|r|}
\hline No. & \multicolumn{1}{|c|}{ NIK } & \multicolumn{1}{|c|}{ NAMA } & \multicolumn{1}{c|}{ PLAFON } & \multicolumn{1}{c|}{ POKOK } & \multicolumn{1}{c|}{$\begin{array}{c}\text { SALDO } \\
\text { PIUTANG }\end{array}$} \\
\hline 1. & 101010010038353 & Samanu & 110.000 .000 & 110.000 .000 & 132.275 .000 \\
\hline 2. & 101010010038381 & Harry Suwarno & 60.277 .750 & 70.000 .000 & 86.317 .950 \\
\hline 3. & 101010010038394 & Sukarni & 2.916 .500 & 5.000 .000 & 3.966 .900 \\
\hline 4. & 101010010038733 & M. Karno & 999.850 & 4.000 .000 & 1.180 .050 \\
\hline 5. & 101010010038892 & Widayati & 2.916 .500 & 5.000 .000 & 3.441 .900 \\
\hline 6. & 101010010038900 & Karji & 12.500 .000 & 25.000 .000 & 11.500 .000 \\
\hline 7. & 101010010038909 & Bambang Sudarsono & 63.888 .600 & 100.000 .000 & 91.489 .400 \\
\hline 8. & 101010010039064 & Sampi Andriasih & 4.500 .000 & 4.500 .000 & 4.950 .000 \\
\hline 9. & 101010010039081 & Nuning Dian Meiningsih & 1.888 .500 & 8.500 .000 & 2.433 .000 \\
\hline 10. & 101010010039108 & Sukirman & 150.000 & 1.500 .000 & 172.500 \\
\hline
\end{tabular}

\section{Preprocessing}

Di dalam preprocessing langkah yang harus dibuat adalah penginisialisasian atau proses penamaan sebuah item ke dalam sebuah penamaan huruf, sehingga dapat mempermudah proses yang akan dibuat. Selain itu dengan adanya preprocessing maka dapat meminimalisir kesalahan pada data yang telah didapat. Data nasabah PT. BPR Ploso Saranaartha Jombang yang telah di preprocessing akan digunakan sebagai dataset pada sistem yang akan dibangun.

\section{Proses Analisa Algoritma ID3}

Dataset data nasabah digunakan untuk membuat pohon keputusan (Decision Tree) yang dimulai dengan pembentukan akar, kemudian data terbagi berdasarkan atribut-atribut yang sesuai untuk dijadikan leaf-node. Tahap ini dimulai dengan melakukan seleksi atribut menggunakan formula information gain untuk masing-masing atribut, yang mana atribut dengan nilai gain tertinggi akan menjadi parent bagi node-node selanjutnya. Node-node tersebut berasal dari atribut-atribut yang memiliki gain yang lebih kecil dari nilai gain atribut parent. Maka untuk mendapatkan nilai gain dari du akelas output yang berbeda yaitu status kredit lancar dan macet.

\section{Rule}

Daftar rule didapat pada setiap path dari setiap root sampai ke sebuah leaf node. Untuk setiap kriteria yang terpisah pada suatu path maka diberi logika 'AND' atau konjungsi pada 
bagian 'IF'. Leaf node memiliki class prediction yang diformulasi untuk rule consequent atau pada bagian 'THEN'. Rule yang didapatkan setelah proses mining adalah sebagai berikut:

$\mathbf{R} \mathbf{1}=$ if pokok pinjaman $=$ tinggi then lancar.

$\mathbf{R 2}=$ if pokok pinjaman $=$ rendah and saldo piutang = besar then lancar.

$\mathbf{R 3}=$ if pokok pinjaman $=$ rendah and saldo piutang $=$ kecil and system pinjaman $=$ angsuran and lama pinjam = iya then lancar.

$\mathbf{R 4}=$ if pokok pinjaman $=$ rendah and saldo piutang $=$ kecil and system pinjaman $=$ angsuran and lama pinjam $=$ tidak and jenis pekerjaan $=$ pns and jenis jaminan $=$ kendaraan bermotor then $90,83 \%$ lancar, $9,17 \%$ macet.

R5 $=$ if pokok pinjaman $=$ rendah and saldo piutang $=$ kecil and system pinjaman $=$ angsuran and lama pinjam $=$ tidak and jenis pekerjaan $=$ pns and jenis jaminan $=$ sertifikat then lancar.

R6 $=$ if pokok pinjaman $=$ rendah and saldo piutang $=$ kecil and system pinjaman $=$ angsuran and lama pinjam $=$ tidak and jenis pekerjaan swasta and jenis jaminan $=$ kendaraan bermotor then $90 \%$ lancar, $10 \%$ macet.

R7 $=$ if pokok pinjaman $=$ rendah and saldo piutang $=$ kecil and sistem pinjaman $=$ angsuran and lama pinjam = tidak and jenis usaha $=$ swasta and jenis jaminan $=$ sertifikat then lancar.

R8 $=$ if pokok pinjaman $=$ rendah and saldo piutang $=$ kecil and system pinjam $=$ musiman and jenis jaminan $=$ kendaraan bermotor then $88 \%$ lancar, $12 \%$ macet.

$\mathbf{R 9}=$ if pokok pinjaman $=$ rendah and saldo piutang $=$ kecil and system pinjaman $=$ musiman and jenis jaminan $=$ sertifikat and jenis pekerjaan $=$ swasta then macet.

$\mathbf{R 1 0}=$ if pokok pinjaman $=$ rendah and saldo piutang $=$ kecil and system pinjaman $=$ musiman and jenis jaminan $=$ sertifikat and jenis pekerjaan $=$ pns then macet.

\section{Implementasi Sistem}

Implementasi sistem untuk penerapan algoritma iterative dichotomizer three (ID3) untuk menentukan kelayakan pemberian kredit pada PT. BPR Ploso Saranaartha Jombang dibangun berbasis web. Bahasa pemrograman yang digunakan adalah PHP 7.2. Sistem secara umum dibagi menjadi beberapa modul yang dirancang dalam bentuk menu sebagaimana yang ditunjukkan pada Gambar 2.

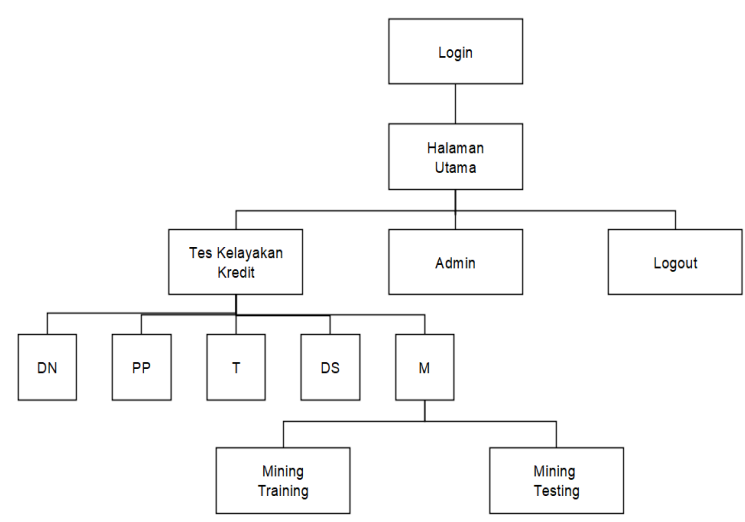

Gambar 2. Struktur Menu Dalam Sistem

Pada saat awal dijalankan, sistem akan menampilkan sebuah form login, pengguna harus login terlebih dahulu untuk mengakses sistem ini. Setelah login selesai, sistem akan menampilkan halaman utama. Pada halaman utama terdapat 3 menu, yaitu menu tes kelayakan kredit, admin, dan logout.

\section{Implementasi Halaman Utama}

Pada menu utama terdapat beberapa menu yaitu Halalam Utama, Mining Testing, Kredit, Administrator, Pengaturan dan Menu Logout. Pada menu Kredit, Administrator dan Pengaturan terdapat submenu, seperti yang ditunjukkan dalam Gambar 3.

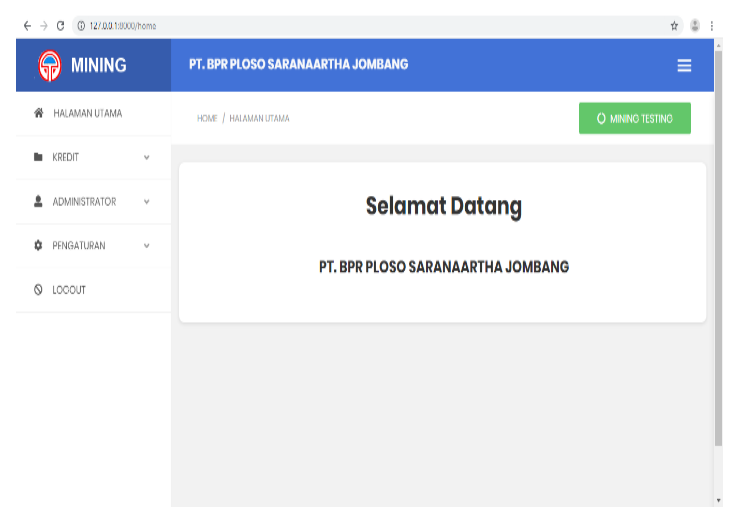

Gambar 3. Halaman Utama

\section{Implementasi Proses Master Admin}

Menu master admin ini digunakan untuk menyimpan data admin. Pada halaman ini dapat menambahkan, mengubah dan menghapus data admin, seperti yang ditunjukkan oleh Gambar 4 . 


\section{DATA ADMIN}

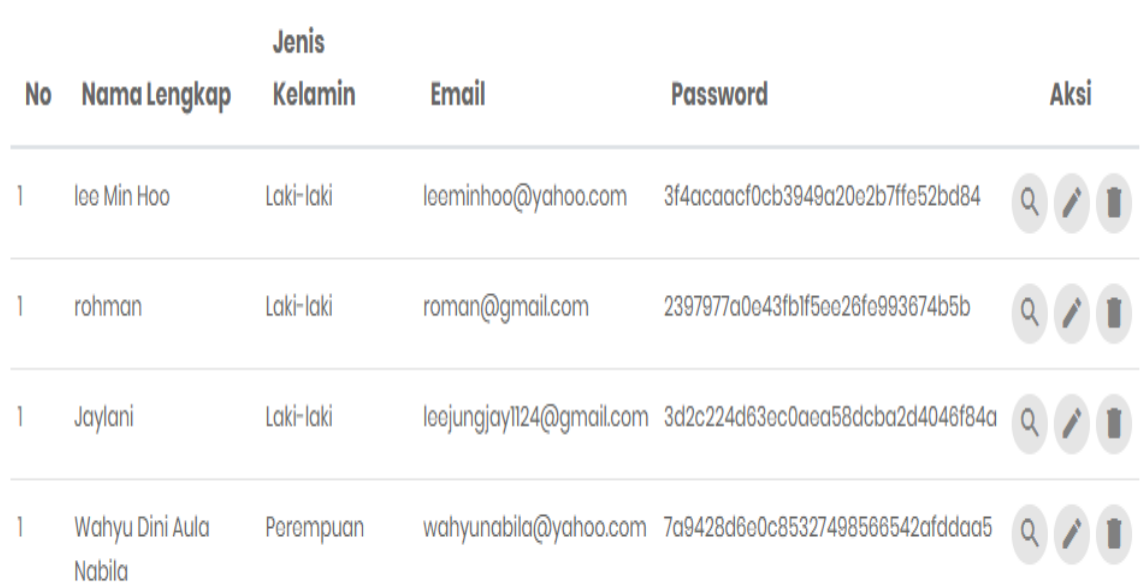

Gambar 4. Form Master Admin

\section{Implementasi Proses Data Mining}

Bagian ini merupakan proses utama pada penerapan aplikasi Data Mining untuk mendapatkan solusi yang diharapkan, dapat dilihat pada gambar 5.

\begin{tabular}{|c|c|c|c|c|c|}
\hline t. IMPORT FILE & Choose File & No file chosen & & & C RESET DATA \\
\hline NIK & Nama Lengkap & Pokok Pinjaman & Jaminan & Jangka & Aksi \\
\hline 1 & SUPARMAN & 45000000 & SERTIFIKAT & 12 bulan & a \\
\hline 2 & ANDIK MUSTOFAH & 3500000 & KEND. BERMOTOR & 6 bulan & a \\
\hline 3 & FIDUL YULIANTO & 3000000 & KEND. BERMOTOR & 18 bulan & a \\
\hline 4 & GANIS CAHYONO & 5000000 & KEND. BERMOTOR & 12 bulan & a \\
\hline 5 & RUPIATI & 2000000 & KEND. BERMOTOR & 12 bulan & a \\
\hline 6 & SRI MUDIYAH & 4000000 & KEND. BERMOTOR & 18 bulan & a \\
\hline 7 & MUIIYADI & 1500000 & KFND. RFRMOTOR & 6 hulan & 0 \\
\hline
\end{tabular}

Gambar 5. Halaman Data Nasabah

Halaman Data Nasabah menampilkan informasi data nasabah yang yang akan digunakan sebagai mining training, pada halaman ini terdapat tombol Import yang digunakan untuk mengimport data nasabah ke database dalam format exel dan pada tombol Reset digunakan untuk menghapus data nasabah. 


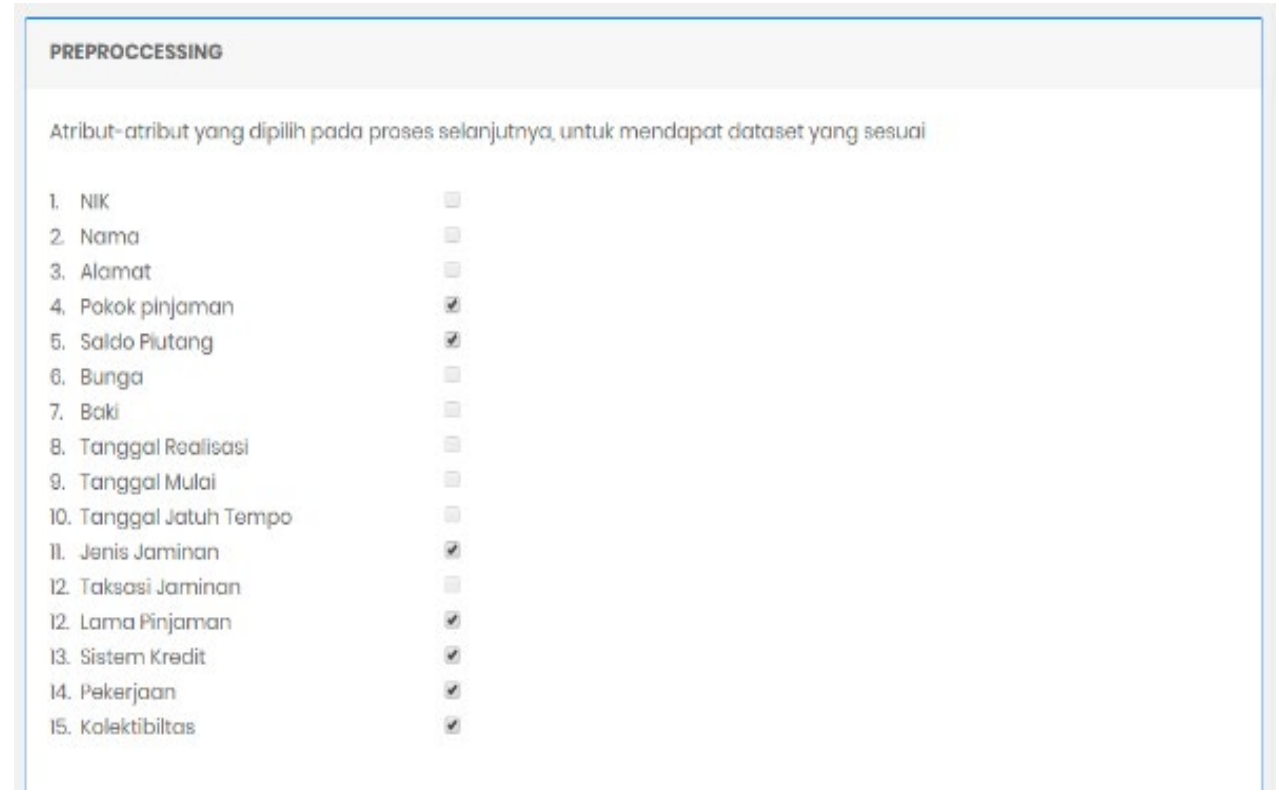

Gambar 6. Halaman Preprocessing

Pada gambar 6 terdapat halaman form preprocessing yang berfungsi untuk tahap yang dilakukan agar mendapat dataset yang sesuai dengan kebutuhan pada sistem. Selain itu juga berfungsi untuk meminimalisir kesalahan yang ada pada data yang telah didapat.

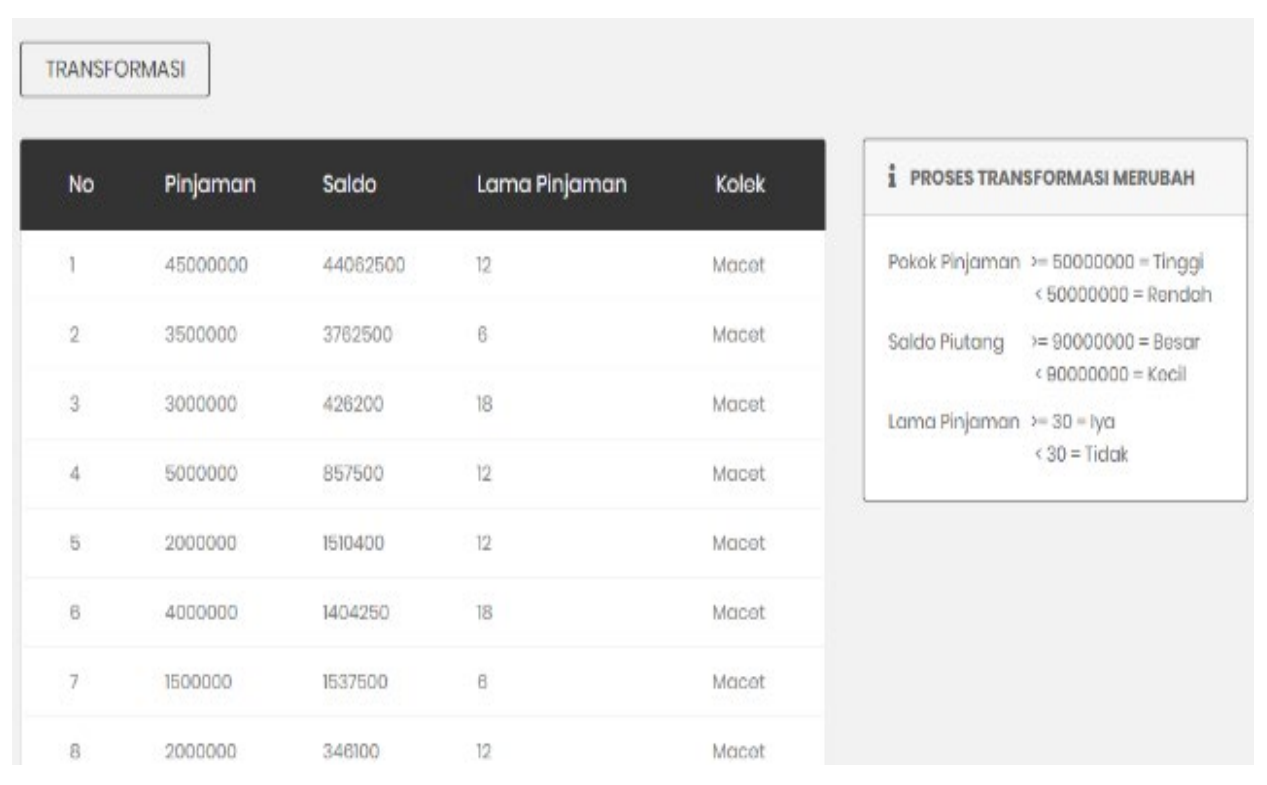

Gambar 7. Halaman Transformasi

Pada gambar 7 dapat dijelaskan bahwa halaman transformasi berfungsi untuk mentransformasi data kedalam bentuk tertentu sehingga data tersebut sesuai untuk proses data mining. Data diubah atau digabung ke dalam format yang sesuai untuk diproses dalam data mining. Beberapa metode data mining membutuhkan format data yang khusus sebelum bisa diaplikasikan. 


\begin{tabular}{|c|c|c|c|c|c|c|c|}
\hline No & Pokok & Saldo & Jaminan & Lama & Usaha & Sistem & Kolektibilitas \\
\hline 1 & Rendah & Kecil & SERTIFIKAT & Tidak & Swasta & MUSIMAN & Macet \\
\hline 2 & Rendah & Kecil & KEND. BERMOTOR & Tidak & PNS & MUSIMAN & Macet \\
\hline 3 & Rendah & Kecil & KEND. BERMOTOR & Tidak & PNS & ANGSURAN & Macet \\
\hline 4 & Rendah & Kecil & KEND. BERMOTOR & Tidak & PNS & ANGSURAN & Macet \\
\hline 5 & Rendah & Kecil & KEND. BERMOTOR & Tidak & Swasta & ANGSURAN & Macet \\
\hline 6 & Rendah & Kecil & KEND. BERMOTOR & Tidak & PNS & ANGSURAN & Macet \\
\hline 7 & Rendah & Kecil & KEND. BERMOTOR & Tidak & PNS & MUSIMAN & Macet \\
\hline 8 & Rendah & Kecil & KEND. BERMOTOR & Tidak & Swasta & ANGSURAN & Macet \\
\hline 9 & Rendah & Kecil & KEND. BERMOTOR & Tidak & Swasta & ANGSURAN & Macet \\
\hline
\end{tabular}

Gambar 8. Halaman Dataset

Halaman dataset pada gambar 8 hanya menampilkan Data Nasabah yang telah di transformasi, Form Dataset berfungsi sebagai data nasabah yang akan di proses kedalam mining. Dataset adalah sebuah file dimana objek adalah record-record (baris) dalam file dan setiap field (kolom) berkaitan dengan sebuah atribut.

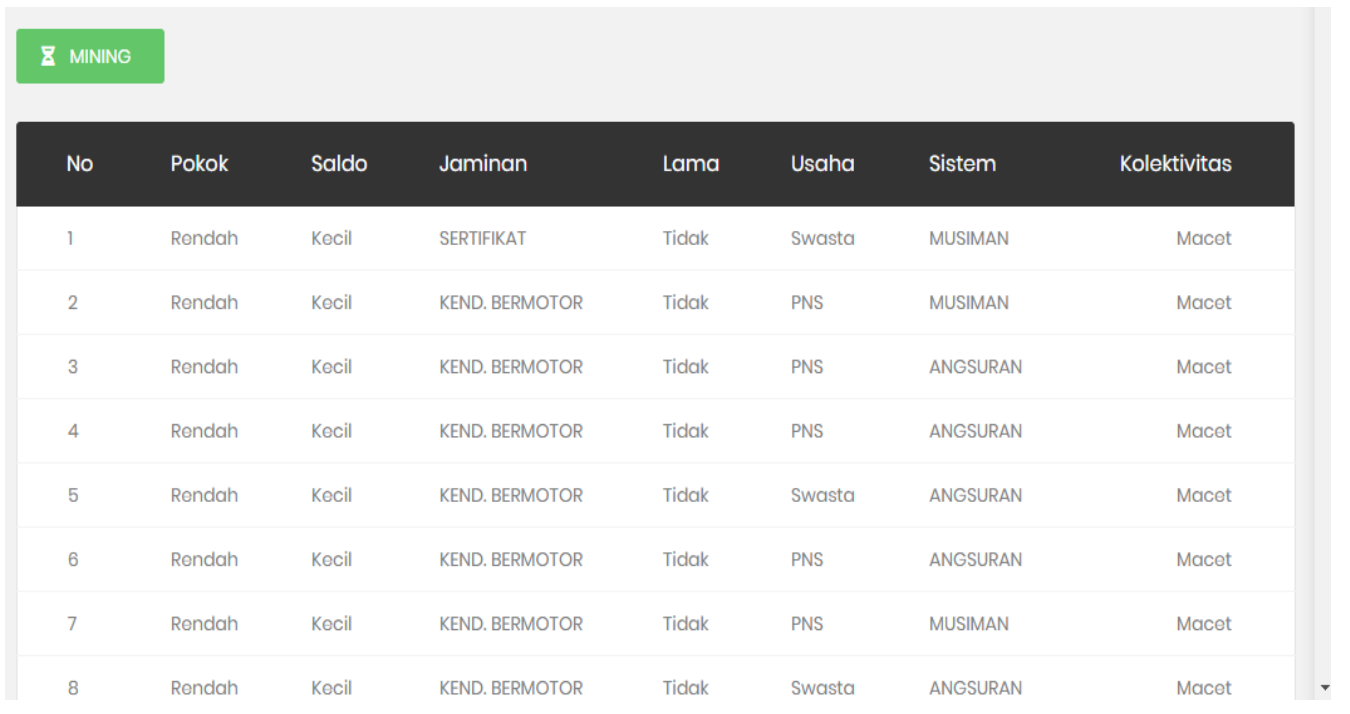

Gambar 9. Halaman Data Mining Training

Form mining training seperti pada gambar 9 berfungsi untuk menghitung atau mencari informasi Dalam pembuatan data mining ini metode yang digunakan aturan asosiasi menggunakan algoritma Iterative Dicothomizer Three (ID3). Metode ini digunakan untuk menemukan hasil akhir berupa kelayakan dan diterimanya calon nasabah PT. BPR Ploso Saranaartha Jombang.

Data akan mengalami proses training, yaitu memproses dengan algoritma Iterative Dichotomizer Three. Proses mencari informasi menarik dalam data terpilih yang sebelumnya belum diketahui dengan menggunakan algoritma ID3. 


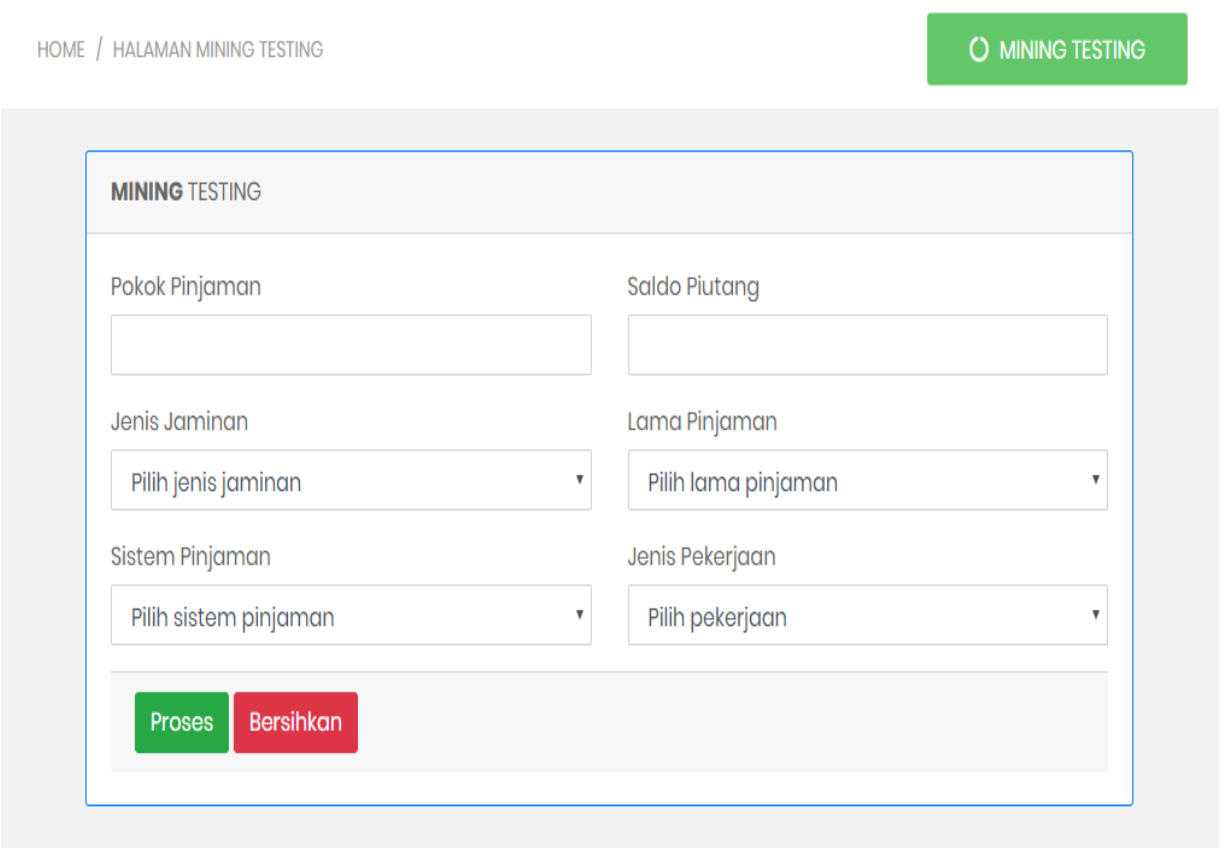

Gambar 10. Halaman Mining Testing

Halaman mining testing pada gambar 10 mempunyai beberapa komponen yang mendukung proses testing dari proses mining yang sudah selesai dan untuk mendapatkan sebuah solusi. Langkah-langkah proses testing adalah sebagai berikut:

1. Pengguna mengisi semua inputan tiap atribut pada textbox sesuai atribut

2. Setelah semua masukan terisi, pengguna dapat mengklik tombol Proses

3. Hasil testing akan tampil sesuai dengan tree/rule yang telah disimpan
4. Pengguna dapat memilih tombol bersihkan berfungsi untuk membersihkan data inputan jika ingin melakukan proses testing lagi.

\section{Pengujian}

Rules pada bagian sebelumnya akan digunakan sebagai acuan pengujian sistem yang telah dibuat. Pengujian sistem ini dilakukan dengan memasukkan data testing ke dalam sistem. Data testing tersebut berisi 20 data nasabah baru. Tabel 2 meruapakan data yang akan digunakan dalam proses pengujian sistem.

Tabel 2. Data Testing

\begin{tabular}{|c|c|c|c|c|c|c|c|}
\hline No & $\begin{array}{c}\text { Pokok } \\
\text { Pinjaman }\end{array}$ & $\begin{array}{c}\text { Saldo } \\
\text { Piutang }\end{array}$ & Jenis Jaminan & $\begin{array}{c}\text { Lama } \\
\text { Pinjam }\end{array}$ & Sistem Pinjaman & $\begin{array}{c}\text { Jenis } \\
\text { Pekerjaan }\end{array}$ & Kolek \\
\hline 1 & 8500000 & 2543000 & SERTIFIKAT & 24 & MUSIMAN & PNS & Macet \\
\hline 2 & 20500000 & 90870000 & KEND. BERMOTOR & 12 & Musiman & PNS & Macet \\
\hline 3 & 25000000 & 28352000 & KEND. BERMOTOR & 6 & MUSIMAN & PNS & Lancar \\
\hline 4 & 2500000 & 2682300 & KEND. BERMOTOR & 24 & ANGSURAN & PNS & Macet \\
\hline 5 & 30000000 & 8540000 & KEND. BERMOTOR & 12 & ANGSURAN & SWASTA & Lancar \\
\hline 6 & 100000000 & 93950400 & SERTIFIKAT & 36 & ANGSURAN & SWASTA & Lancar \\
\hline 7 & 4500000 & 4950000 & KEND. BERMOTOR & 6 & MUSIMAN & PNS & Lancar \\
\hline 8 & 1000000 & 115000 & KEND. BERMOTOR & 10 & ANGSURAN & SWASTA & Lancar \\
\hline 9 & 13000000 & 15735400 & KEND. BERMOTOR & 24 & ANGSURAN & SWASTA & Lancar \\
\hline 10 & 8500000 & 2433000 & KEND. BERMOTOR & 18 & ANGSURAN & SWASTA & Lancar \\
\hline 11 & 2500000 & 3675000 & KEND. BERMOTOR & 10 & ANGSURAN & PNS & Macet \\
\hline 12 & 5000000 & 2313500 & KEND. BERMOTOR & 36 & ANGSURAN & PNS & Lancar \\
\hline 13 & 9000000 & 8800000 & KEND. BERMOTOR & 12 & ANGSURAN & SWASTA & Lancar \\
\hline 14 & 7500000 & 6450400 & KEND. BERMOTOR & 18 & ANGSURAN & PNS & Lancar \\
\hline 15 & 85000000 & 62970000 & SERTIFIKAT & 30 & MUSIMAN & PNS & Lancar \\
\hline 16 & 8000000 & 5060050 & KEND. BERMOTOR & 18 & ANGSURAN & PNS & Lancar \\
\hline 17 & 1000000 & 918000 & KEND. BERMOTOR & 10 & ANGSURAN & PNS & Lancar \\
\hline 18 & 3000000 & 1057500 & KEND. BERMOTOR & 18 & ANGSURAN & SWASTA & Macet \\
\hline 19 & 45000000 & 37050900 & SERTIFIKAT & 12 & MUSIMAN & PNS & Macet \\
\hline 20 & 70000000 & 55982000 & KEND. BERMOTOR & 30 & ANGSURAN & SWASTA & Lancar \\
\hline
\end{tabular}


Setelah memasukkan data tersebut ke dalam sistem, maka diperoleh perbandingan output antara data asli dan data yang sudah dimasukkan ke sistem untuk dilakukan proses testing seperti pada tabel 3 .

Tabel 3. Perbandingan Output

\begin{tabular}{|c|c|c|c|}
\hline Data Ke & Data Asli & Data Hasil Testing & Error \\
\hline 1 & Macet & Macet & $0 \%$ \\
\hline 2 & Macet & Lancar & $100 \%$ \\
\hline 3 & Lancar & $88 \%$ Lancar $12 \%$ Macet & $12 \%$ \\
\hline 4 & Macet & 90,83\% Lancar $9,17 \%$ Macet & $9,17 \%$ \\
\hline 5 & Lancar & 90\% Lancar $10 \%$ Macet & $10 \%$ \\
\hline 6 & Lancar & Lancar & $0 \%$ \\
\hline 7 & Lancar & $88 \%$ Lancar $12 \%$ Macet & $12 \%$ \\
\hline 8 & Lancar & 90\% Lancar $10 \%$ Macet & $10 \%$ \\
\hline 9 & Lancar & 90\% Lancar $10 \%$ Macet & $10 \%$ \\
\hline 10 & Lancar & 90\% Lancar $10 \%$ Macet & $10 \%$ \\
\hline 11 & Macet & 90,83\% Lancar $9,17 \%$ Macet & $9.17 \%$ \\
\hline 12 & Lancar & Lancar & $0 \%$ \\
\hline 13 & Lancar & $90 \%$ Lancar $10 \%$ Macet & $10 \%$ \\
\hline 14 & Lancar & $90,83 \%$ Lancar $9,17 \%$ Macet & $9,17 \%$ \\
\hline 15 & Lancar & Lancar & $0 \%$ \\
\hline 16 & Lancar & $90,83 \%$ Lancar $\quad 9,17 \%$ Macet & $9,17 \%$ \\
\hline 17 & Lancar & $90,83 \%$ Lancar $9,17 \%$ Macet & $9,17 \%$ \\
\hline 18 & Macet & 90\% Lancar $10 \%$ Macet & $10 \%$ \\
\hline 19 & Macet & Macet & $0 \%$ \\
\hline 20 & Lancar & Lancar & $0 \%$ \\
\hline Total Error & $229,85 \%$ & & \\
\hline $\begin{array}{r}\text { Rata-Rata } \\
\text { Error }\end{array}$ & $11,49 \%$ & & \\
\hline
\end{tabular}

Hasil dari output data yang digunakan sebagai testing tersebut ternyata dapat mengcover beberapa rules, diantaranya:

1. Data 1 memenuhi rules nomor 10 karena pokok pinjaman rendah dan saldo piutang kecil dan sistem pinjaman musiman dan jenis jaminan sertifikat dan jenis pekerjaan pns maka macet.

2. Data 3 memenuhi rules nomor 8 karena pokok pinjaman rendah dan saldo piutang kecil dan sistem pinjaman musiman dan jenis jaminan kendaraan bermotor maka $88 \%$ lancar $12 \%$ macet.

3. Data 4 memenuhi rules nomor 4 karena pokok pinjaman rendah dan saldo piutang kecil dan sistem pinjaman angsuran dan lama pinjam tidak dan jenis pekerjaan pns dan jenis jaminan kendaraan bermotor maka $90,83 \%$ lancar $9,17 \%$ macet.

4. Data 5 memenuhi rules nomor 6 karena pokok pinjaman rendah dan saldo piutang kecil dan sistem pinjaman angsuran dan lama pinjam tidak dan jenis pekerjaan swasta dan jenis jaminan kendaraan bermotor maka $90 \%$ lancar $10 \%$ macet.

5. Data 6 memenuhi rules nomor 1 karena pokok pinjaman tinggi maka lancar.

6. Data nomor 12 memenuhi rules nomor 3 karena pokok pinjaman rendah dan saldo piutang kecil dan sistem pinjaman angsuran dan lama pinjam iya maka lancar.

Hasil dari sampel pengujian sebanyak 20 data nasabah menghasilkan tingkat keakurasian sebesar:

$100-11,49=88,51 \%$

\section{PENUTUP}

\section{Kesimpulan}

Berdasarkan uraian dan pembahasan sebelumnya, maka dapat diambil kesimpulan diantaranya metode ID3 dapat diaplikasikan pada pembuatan atau pengembangan sistem dalam menentukan kelayakan pengajuan kredit pada PT. BPR Ploso Saranaartha Jombang, 
Selain itu dengan adanya sistem ini maka penentuan nasabah yang layak diberikan pinjaman pada PT. BPR Ploso Saranaartha Jombang dapat dilakukan dengan cepat, dimana sistem yang telah dikembangkan dapat dipakai sebagai rekomendasi untuk pemberian kelayakan kredit dengan tingkat keakurasian 88,51\%.

\section{Saran}

Pada penelitian ini dalam hal menghitung impurity measure atau kelas atribut dari suatu simpul dalam pohon klasifikasi menggunakan classification error. Untuk menghasilkan hasil yang lebih akurat bisa mengguanakan metode klasifikasi yang lain.

\section{REFERENSI}

[1] E. Andayani, "Konsep dan Kerangka Dasar Sistem Informasi Manajemen," Sist. Inf. Manajeman, pp. 1-45, 2010.

[2] M. Fuady, H. P. Kontemporer, and C. A. Bakti, "Munir Fuady, Hukum Perkreditan Kontemporer , Citra Aditya Bakti, Bandung, 2002, h. 5."

[3] Hariati, M. Wati, and B. Cahyono, "Penerapan Algoritma C4.5 Decision Tree pada Penentuan Penerima Program Bantuan Pemerintah Daerah Kabupaten Kutai Kartanegara," Jurti, vol. 2, no. 1, pp. 27-36, 2018.

[4] I. Choina, R. Aulia, and A. Zakir, "Penerapan Algoritma ID3 Untuk Menyeleksi Pegawai Kontrak Di Kantor Pengadilan Kota Langsa," CESS (Journal Comput. Eng. Syst. Sci., vol. 5, no. 1, pp. 47-52, 2020.

[5] Ilayani, J. Nangi, and yuwanda purnamasari Pasrun, "APLIKASI DATA MINING UNTUK PENILAIAN KREDIT MENGGUNAKAN DECISION TREE ALGORITMA ID3 STUDI KASUS PT. MANDALA MULTI FINANCE CABANG KENDARI Ilayani*1," semanTIK, vol. 4, no. 1, pp. 65-76, 2018.

[6] M. Y. Helmy and D. Kushartantya, "Implementasi Data Mining Untuk Memprediksi Kelayakan Permintaan Pinjaman Nasabah Di Lembaga Keuangan," vol. 2, no. 1, pp. 267-274, 2013. 